\title{
Epidemiological profile of patients with red eye complain treated at Fundação Hilton Rocha, MG, Brazil
}

\author{
Perfil epidemiológico dos pacientes atendidos com queixa \\ de olho vermelho na Fundação Hilton Rocha, MG, Brazil
}

Camila Amaral Carvalho Cunha' ${ }^{1}$ Érica de Abreu Borges ${ }^{1}$, Hévila Rolim²

\begin{abstract}
Objective: Determining the epidemiological factors and analyzing the main etiological causes of the patients treated with red-eye complaint at the urgency and emergency sector of the ophthalmological hospital in the state of Minas Gerais. Methods: A prevalence observational analytical study was performed with a non-probabilistic sample formed by patients who visited the emergency room of the Fundação Hilton Rocha Hospital from january to april 2014 ( $n=1140)$. The following variables investigated were: gender, age, race, profession, education, income, means of transportation, time elapsed between the first symptom and the first visit, day of the week, low visual acuity symptom, diagnosis and treatment. Results: Out of the sample of 390 patients with red eye complaint, $57.4 \%(n=224)$ were female and the age ranged from 3 to 97, with an average of 43.7 years of age. The majority of patients, $87.6 \%(n=341)$ sought the service up to 14 days after the onset of symptoms, only 75 individuals (19.4\%) had low visual acuity. The lower economic classes (classes D and E) are prevalent among patients. The main cause of red eye complain was conjunctivitis and infectious blepharoconjunctivitis $32.6 \%$ ( $n=127)$. Conclusion: Infectious conjunctivitis was the morbidity with the highest incidence. The Fundação Hilton Rocha plays an important role in providing urgent ophthalmological care in the public health network in Minas Gerais. It is important to identify the most frequent causes of medical service for ocular diseases and expand the epidemiological and social studies in order to improve people's access to ophthalmic emergencies and give us subsidies for guidance campaigns, focused mainly on the lower social classes.

Keywords: Conjunctivitis/diagnosis; Conjunctivitis/epidemiology; Conjunctivitis/etiology; Eye diseases/epidemiology; Emergency service, hospital
\end{abstract}

\section{ReSUMO}

Objetivo: Determinar os fatores epidemiológicos e analisar as principais causas etiológicas dos pacientes atendidos com queixa de olho vermelho no setor de urgência e emergência de um hospital oftalmológico de ensino do estado de Minas Gerais. Métodos: Foi realizado um estudo de prevalência observacional, analítico com amostra não probabilística formado pelos pacientes que compareceram no setor de urgência da Fundação Hilton Rocha nos meses de janeiro a abril de 2014 ( $\mathrm{n}=1140)$. Foram analisadas as seguintes variáveis: gênero, idade, raça, profissão, escolaridade, renda, meio de transporte, tempo decorrido entre o sintoma inicial e o primeiro atendimento, dia da semana, presença de baixa da acuidade visual e diagnóstico. Resultados: A amostra apresentou 390 pacientes com queixa de olho vermelho, 57,4\% ( $n=224)$ eram do sexo feminino, a idade variou entre 3 e 97 anos, sendo a média de 43,7 anos. A maioria dos pacientes $(87,6 \%, \mathrm{n}=341)$ procurou o serviço em até 14 dias do início dos sintomas e apenas 75 indivíduos $(19,4 \%)$ apresentavam baixa acuidade visual. As classes econômicas inferiores (classes D e E) são predominantes entre os atendidos. A principal causa da queixa de olho vermelho foi conjuntivite e blefaroconjuntivite infecciosas (32,6\%, $n=127)$. Conclusão: A conjuntivite infecciosa foi a morbidade de maior incidência. A Fundação Hilton Rocha desempenha um papel importante no atendimento à urgência oftalmológica da rede pública de Minas Gerais, sendo importante identificar as principais causas de atendimento e ampliar os estudos epidemiológicos e sociais, a fim de melhorar o acesso da população às urgências oftalmológicas e nos dar subsídios para campanhas de orientação, voltadas principalmente para as classes sociais menos favorecidas.

Descritores: Conjuntivite/diagnóstico; Conjuntivite/epidemiologia; Conjuntivite/etiologia; Oftalmopatias/epidemiologia; Serviço hospitalar de emergência

\footnotetext{
${ }^{1}$ Fundação Hilton Rocha, Associação Educativa do Brasil - Soebras/FUNORTE - Belo Horizonte (MG), Brasil;

2 Universidade Federal de Rondônia - Porto Velho (RO), Brasil.
}

Study conducted at Fundação Hilton Rocha, Educational Association of Brazil - Soebras/FUNORTE - Belo Horizonte, MG, Brazil. The authors declare no conflict of interests. 


\section{INTRODUCTION}

$\mathbf{R}$ ed eye is a common complaint present in an ophthalmic emergency service $(1,2)$ and is responsible for about $15 \%$ of the ophthalmological appointments and $6 \%$ of appointments with general practitioners(1). Red eye signs and symptoms include hyperemia, pain, photophobia, itching and changes in visual acuity.

The onset of red eye, or conjunctival hyperemia, is caused by vasodilation of the blood vessels of the conjunctiva and/or episclera and sclera. The increased conjunctival hyperemia is a clinical symptom of various diseases of the eye surface (3). This manifestation covers a wide group of diseases, and its differential diagnosis is essential. Conjunctivitis is the most common cause of red eye (4-7).

The economically active population is more present in emergency ocular care, demonstrating the impact of ophthalmologic diseases in this socio-economic sector (4). There are certain types of professions that expose the individual to ocular risks, such as trauma and foreign body. In Brazil, $10 \%$ of work accidents are ocular. Workers in the construction sector and motorcyclists are considered risk professions. Among the ocular traumas due to occupational accidents, the most common finding $(48.7 \%)$ is the superficial foreign body (8).

Although the majority of red-eye causes is a benign and self-limiting condition, the identification and appropriate treatment of serious diseases avoid serious consequences, such as blindness $(9,10)$.

Fundação Hilton Rocha is a federal philanthropic organization which attends a diverse population representative of the State of Minas Gerais. 4330 patients were assisted at the emergency sector in 2012, and 3160 patients in 2013. This study aims at determining the epidemiological factors and analyzing the main etiologic causes of the patients complaining of red eye in urgency and emergency sector of the ophthalmological hospital, in order to improve the emergency care and plan preventive strategies.

\section{Methods}

Was conducted an analytical and observational study with the prevalence of red eye complaints in a non-probability sample formed by patients who were attended in the urgency sector of Fundação Hilton Rocha between the months of January to April $2014(\mathrm{n}=1140)$. Patients complaining of red eye $(n=390)$ formed the target population of the study. The study was approved by the Research Ethics Committee of SOEBRAS, according to opinion CAAE 035.0.203.000-11. The participants or their legal guardians have been verbally and in writing informed about the nature and purpose of the study. Individuals who attended the urgency sector for follow-up appointment were not included in the study.

Demographic and clinical data (gender, age, race, occupation, education, income, means of transportation, time elapsed between the initial symptoms and the first care, day of the week of the appointment, presence of low visual acuity and diagnosis) were collected by a standard questionnaire applied by one of the researchers and by medical record review. The red eye was classified as to the degree of hyperemia in a system of crosses, according to Murphy et al. (3), being + minimum hyperemia; ++ mild; +++ moderate and ++++ severe.
The ethnicity was determined by self-classification according to the criteria of the Brazilian Institute of Geography and Statistics (IBGE) (11). Social classes were determined according to the Center for Social Policies at the Getulio Vargas Foundation and are divides into: class A (more than 18 minimum wages), class B (from 14 to 18 minimum wages), class $\mathrm{C}$ (from 03 to 14 minimum wages), class D (from 01 to 03 minimum wages) and class $\mathrm{E}$ (0 to 01 minimum wage) (12).

To profile the sample, frequency tables were built with the number of occurrence and their respective percentages for categorical variables and the measures of central tendency (mean and median) and dispersion (standard deviation) were calculated for the quantitative variables. The program used was SPSS version 20.0. P values less than 0.05 were considered statistically significant.

\section{ReSULTS}

From a total of 1140 patients, 390 patients complained of red eye, being 224 (57.4\%) females and 166 (42.6\%) males. The average age was 43.7 years (standard deviation: 20.7 years) and ranged from 3 to 97 years.

As to ethnicity, 144 (36.9\%) of the patients were white, 84 (21.5\%) black, $160(40.8 \%)$ brown, and only one case $(0.8 \%)$ was yellow. Regarding education, it was observed that 143 $(36.7 \%)$ patients had no education or had incomplete elementary 1st cycle, $134(34.4 \%)$ had complete elementary 1st cycle or incomplete elementary 2nd cycle, and $113(28,9 \%)$ had complete elementary 2 nd cycle or more. A percentage of $13.4 \%$ $(n=52)$ of the population of the study declared no income.

Regarding social class, most of this population belonged to class $\mathrm{E}(\mathrm{n}=145 ; 37.1 \%)$ and class $\mathrm{D}(\mathrm{n}=145 ; 37.1 \%)$, while the remaining patients $(n=48 ; 12,3 \%)$ belonged to classes $C$ and $D$ and none belonged to class $\mathrm{A}$. The economically active group (self-employed, employees, employers and unemployed) consisted of $266(68.2 \%)$ people, and $124(31.8 \%)$ individuals were in the not economically active group (students, retired and disabled). In only 48 cases (12.4\%), patients had a hazard function to ocular hyperemia. The bus was the most widely used means of transportation for access to the hospital $(n=242 ; 62 \%)$.

The most frequent diagnosis was infectious conjunctivitis and blepharoconjunctivitis $(\mathrm{n}=127 ; 32.6 \%)$, followed by postoperative complications $(\mathrm{n}=58 ; 14.7 \%)$. Among the postoperative complications, the most common causes of red eye complaint were incorrect topical steroid weaning $(\mathrm{n}=21$; $36.2 \%)$, ceratites ( $\mathrm{n}=19 ; 32.8 \%)$, loose sutures or corneal routes and conjunctival resulting from corneal transplantation and pterygium excision $(\mathrm{n}=13 ; 22.4 \%)$ and increased intraocular pressure $(\mathrm{n}=5 ; 8.6 \%)$. The eye trauma had little expressiveness $(\mathrm{n}=12 ; 3.1 \%)$, as shown in table 1 . The characterization of patients with respect to data of complaint clinical of red eye is presented in table 2 .

The majority of patients $(n=344 ; 87.6 \%)$ sought hospital care within 14 days of symptom onset. The low visual acuity was found in a few cases $(n=75 ; 19.4 \%)$ (Table 2$)$.

It was noted an increased number of cases with minimal hyperemia (1+) as the time between the appearance of red eye and the demand for emergency care $(\mathrm{p}=0.0072)$ increased (Figure 1). No significant association was found between low visual acuity and the degree of hyperemia $(\mathrm{p}=0.124)$. 
Table 1

Diagnosis of red eye

\begin{tabular}{|c|c|}
\hline Diagnosis & $\mathbf{N}(\%) *$ \\
\hline \multicolumn{2}{|l|}{ Infectious conjunctivitis and } \\
\hline Postoperative complications & $58(14.7)$ \\
\hline Foreign body & $49(12.4)$ \\
\hline \multicolumn{2}{|l|}{ Eye surface disease } \\
\hline (dry eye and ceratites) & $36(9.3)$ \\
\hline Conjunctival degenerations & $33(8.5)$ \\
\hline Eye allergies & $24(6.2)$ \\
\hline Corneal Ulcer & $15(3.9)$ \\
\hline Acute glaucoma & $15(3.9)$ \\
\hline Subconjunctival hemorrhage & $12(3.1)$ \\
\hline Trauma & $12(3.1)$ \\
\hline Scleritis and episcleritis & $6(1.5)$ \\
\hline Endophthalmitis & $3(0.8)$ \\
\hline Total & $390(100)$ \\
\hline \multicolumn{2}{|c|}{$* \mathrm{~N}=$ total number of patients complaining of red eye } \\
\hline \multicolumn{2}{|c|}{ Table 2} \\
\hline \multicolumn{2}{|c|}{ Clinical evaluation of patients with red eye complaints } \\
\hline Variables & $\mathbf{N}(\%)$ \\
\hline \multicolumn{2}{|c|}{ Time between symptom and search for Emergency } \\
\hline Acute (within 14 days) & $344(87.6)$ \\
\hline Subacute ( 15 days to 3 months) & $23(6.2)$ \\
\hline Chronic (Over 3 months) & $23(6.2)$ \\
\hline Total & $390(100)$ \\
\hline \multicolumn{2}{|l|}{ Low visual acuity } \\
\hline No & $315(80.6)$ \\
\hline Yes & $75(19.4)$ \\
\hline Total & $390(100)$ \\
\hline \multicolumn{2}{|l|}{ Degree of hyperemia } \\
\hline+ & $182(46.5)$ \\
\hline++ & $151(38.8)$ \\
\hline+++ & $42(10.8)$ \\
\hline ++++ & $15(3.9)$ \\
\hline Total & $390(100)$ \\
\hline
\end{tabular}

$* \mathrm{~N}=$ total number of patients complaining of red eye

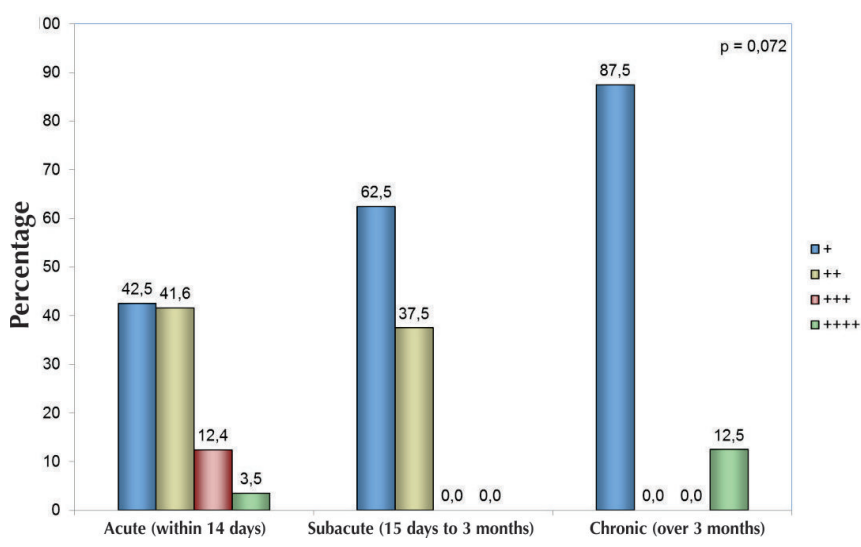

Figure 1: : Characterization percentage of patients in relation to the degree of hyperemia considering time of the patient's symptoms

\section{DISCUSSION}

In this study, there was a predominance of females, diverging from the results of other epidemiological studies that reported the male gender as predominant: $72 \%$ by Araujo et al. (4), $64,84 \%$ by Rocha et al. (5), 66\% by Kara-Junior et al. (6), 54,2\% by Pereira et al. (7), $89 \%$ by Cecchetti et al. (13). The reason for this discrepancy has not been clarified.

The most prevalent age group was between 19 and 60 years $(63.6 \%)$, and fits in economically active age, which resembles the results found in the literature $(5-7,13)$. These findings corroborate the fact that the economically active population is the most vulnerable one to eye diseases in urgency care. The prevailing socio-economic characteristics of these individuals were belonging to less favoured social classes, (D) and $(\mathrm{E})$, in which the most common level of education is low and in which the public transportation (bus) is the most widely used means of locomotion. This finding may have been biased because the attendance of patients in the urgency and emergency service at Fundação Hilton Rocha is from the Brazilian Unified Health System.

As for the diagnostic causes, the main one was infectious conjunctivitis and blepharoconjunctivitis, in agreement with the literature (4-7). Kara-Junior et al. (6) presented infectious diseases as the leading causes of attendance $(34 \%)$, followed by trauma $(20 \%)$ and tumors $(11 \%)$. Most individuals $(87.6 \%)$ attended at Fundação Hilton Rocha had a profession that offered no increased risk of red eye complaint, reinforcing the fact that infectious conjunctivitis was the main cause of red eye, affecting professionals of all areas.

Postoperative complications were the second leading cause of red eye, probably because Fundação Hilton Rocha is a teaching hospital with a high flow of surgical procedures, on average 165 surgeries monthly. Patients get postoperative care in pre-scheduled appointments, and are advised to seek the hospital emergency in the event of complications during the recovery period. There was no correlation between this data and the studies mentioned, as these authors did not isolate postoperative complications as a cause of red eye complaint, having probably been inserted among other diagnostics.

In this study, the foreign body was identified as the third main cause of red eye, and trauma was present only in $3.1 \%$ of cases. These findings are in agreement with the work of Pereira et al. (7), which identified conjunctivitis $(27.91 \%)$ and foreign body $(12.86 \%)$ as the main causes of red eye, with ocular trauma showing little expression $(2.23 \%)$. Possibly the low percentage of trauma as a cause of red eye is due to the existence of referral hospitals of trauma and multiple trauma in the city of Belo Horizonte, and due to the difficult access to Fundação Hilton Rocha by public transportation.

\section{Conclusion}

The red eye complaint is prevalent in ophthalmic urgency service, and infectious conjunctivitis is the morbidity with the highest incidence in this study. The development of strategies aimed at awareness and prevention of new cases and infectious disease outbreaks is necessary. The demand for care is higher in the economically active class. Educational and supervisory measures could help reduce the impact on the income of companies due to the decrease in workers laid off. 
Fundação Hilton Rocha plays an important role in attending ophthalmic urgency in the public service of Minas Gerais. It is important to identify the main causes of care and extend the social and epidemiological studies to improve access of the population to the ophthalmological emergency. These studies may also provide information for guidance campaigns aimed mainly at the lower social classes and the economically active population.

\section{ReFERENCES}

1. Seth D, Khan FI. Causes and management of red eye in pediatric ophthalmology. Curr Allergy Asthma Rep. 2011;11(3):212-9. Review.

2. Cronau H, Kankanala RR, Mauger T. Diagnosis and management of red eye in primary care. Am Fam Physician. 2010 Jan 15;81(2):137-44. Review.

3. Murphy PJ, Lau JS, Sim MM, Woods RL. How red is a white eye? Clinical grading of normal conjunctival hyperaemia. Eye (Lond). 2007;21(5):633-8.

4. Araujo AA, Almeida DV, Araujo VM, Goes MR. Urgência oftalmológica: corpo estranho ocular ainda como principal causa. Arq Bras Oftalmol. 2002;65(2):223-7.

5. Rocha MN, Ávila M, Cruvinel I, Oliveira LL, Mendonça LS. Análise das causas de atendimento e prevalência das doenças oculares no serviço de urgência. Rev Bras Oftalmol. 2012;71(6):380-4.

6. Kara-Junior N, Zanatto MC, Villaça VT, Nagamati LT, Kara-José N. Aspectos médicos e sociais no atendimento oftalmológico de urgência. Arq Bras Oftalmol. 2001;64(1):39-43.
7. Pereira FB,Frasson M, D'Almeida AG,Almeida A, Faria D, Francis J, Medeiros JN. Perfil da demanda e morbidade dos pacientes atendidos em centro de urgências oftalmológicas de um hospital universitário. Rev Bras Oftalmol. 2011;70(4):238-42.

8. Aguiar U J, Rodrigues C K. Estudo de 434 casos de corpos estranhos corneias no Hospital Universitário da Universidade Federal de Santa Catarina. Arq Catarin Med. 2006;35(2):56-62.

9. Mahmood AR, Narang AT. Diagnosis and management of the acute red eye. Emerg Med Clin North Am. 2008;26(1):35-55, vi.

10. Noble J, Lloyd JC. The red eye. CMAJ. 2011;183(1):81.

11. Instituto Brasileiro de Geografia e Estatística (IBGE). Censo demográfico 2010. [Internet]. [citado 2015 Fev 23]. Disponível em: www.ibge.gov.br/home/estatistica/populacao/censo/2010

12. Fundação Getúlio Vargas (FGV). Centro de Políticas Sociais. São Paulo: FGV; 2014. [citado 2015 Fev 23]. Disponível em: www.cps.fgv.br/cps/ncm 2014

13. Cecchetti DF, Cecchetti SA, Nardy AC, Carvalho SC, Rodrigues Mde L, Rocha EM. [A clinical and epidemiological profile of ocular emergencies in a reference emergency center]. Arq Bras Oftalmol. 2008;71(5):635-8. Portuguese.

\section{Corresponding author:}

Camila Amaral Carvalho Cunha

Av José do Patrocínio Pontes, 1355 - Mangabeiras, Belo

Horizonte - MG, Brazil, 30210-090

Phone: (31) 91585502

E-mail: ca_medpa@hotmail.com 